\title{
Introduction
}

\section{The Second Crusade: Main Debates and New Horizons}

\author{
Jason T. Roche
}

The modern era of Second Crusade studies began with a seminal article by Giles Constable entitled 'The Second Crusade as seen by Contemporaries' (1953). Constable focuses on the central role of Pope Eugenius III and his fellow Cistercian, Abbot Bernard of Clairvaux, in the genesis and expansion in scope of the Second Crusade. He pays particular attention to what has become known as the Syrian campaign. But his central thesis maintains that by the spring of 1147 and the issuing of the papal bull Divina dispensatione (II), Pope Eugenius III 'viewed and planned' the venture as a general Christian offensive against a number of the Church's enemies. Thus, the siege of the Syrian Muslim city of Damascus in 1148 and the expeditions of the same year directed against the Baltic strongholds of Dobin, Demmin and Szczecin situated in the pagan Slav lands east of the River Elbe formed part of what we now call the Second Crusade. The supposed scope of the venture was even greater than this: the Christian attacks on the Muslim-held Iberian cities and strongholds of Santarém, Lisbon, Cinta, Almada and Palmela in 1147, Faro, Almería and Tortosa in 1148, and Lérida and Fraga in 1149 also formed part of the same single enterprise to secure and expand the peripheries of Latin Christendom. ${ }^{1}$

Constable's work has proved very influential over the past two decades. The volume of articles entitled The Second Crusade and the Cistercians (1992), edited by Michael Gervers, addresses the impact of Cistercian monks on the crusade movement. The Second Crusade: Scope and Consequences (2001), edited by Jonathan Phillips and Martin Hoch, is a volume of diverse articles which concentrate on the recruitment and consequences of some of the various expeditions identified by Constable. In 2007, Jonathan Phillips published The Second Crusade: Extending the Frontiers of Christendom. The first monograph on the Second Crusade published since Bernard Kugler's Studien zur Geschichte des Zweiten Kreuzzugs (1866), Phillips's study combines a great deal of original research and insight, while being able to draw on the most recent advances in modern scholarship. Discussions on the genesis of the various expeditions and chapters on the different theatres of war as identified by Constable provide the framework for Phillips's study. ${ }^{2}$

${ }^{1}$ Giles Constable, 'The Second Crusade as Seen by Contemporaries', Traditio 9 (1953), 213-79; Eugenius III, no. 3, in Pommersches Urkundenbuch, ed. Klaus Conrad and others, 2nd edn, 9 vols (Köln, 1970-), 1: 36-37, reprinted in Hans-Dietrich Kahl, 'Crusade Eschatology as Seen by St Bernard in the Years 1146 to 1148', in The Second Crusade and the Cistercians, ed. Michael Gervers (New York, 1992), pp. 35-48 (here pp. 43-44).

${ }^{2}$ The Second Crusade and the Cistercians, ed. Gervers; The Second Crusade: Scope and Consequences, ed. Jonathan Phillips and Martin Hoch (Manchester, 2001); Jonathan Phillips, The Second Crusade: Extending the Frontiers of Christendom (New Haven, 2007); Bernard Kugler, Studien zur Geschichte des Zweiten Kreuzzugs (Stuttgart, 1866). 
The recent accumulation of major works on the Second Crusade has thrown a great deal of light on the complex character of this remarkable mid-twelfth-century endeavour. Nonetheless, the inclination to focus on the origins of the well-known expeditions and on the crusade in the Levant has tended to obscure the impact of the various campaigns on the societies they encountered and on the peripheral regions which might have been affected by preaching for the Second Crusade. This volume will readdress this relative neglect by placing established, contentious and new events and concepts associated with the enterprise in a wider ideological, chronological, geopolitical and geographical context.

This introductory article serves a number of purposes. It offers an abridged narrative of the scope of the Second Crusade and introduces the major debates associated with the venture. All the contributions to the present volume are introduced within this framework and, when applicable, their place in the current historiography is highlighted. While serving as a concise introduction to the multifaceted nature of the crusade and, for the first time, drawing attention to the main debates associated with it within a single article, this approach will also underscore the editors' reasoning for the need for a further collection of articles on this extraordinary phenomenon.

The very scope of the Second Crusade is a source of contention. A number of contemporary commentators were aware of a causal relationship between different campaigns. Helmold of Bosau, writing around 1170, famously recorded that the 'initiators of the expedition' formed a plan to instigate campaigns to the East, Iberia and against the pagan Slavs. Hindsight must explain this unique claim: Helmold evidently knew that the fighting on the different fronts was somehow linked and assumed that the conflict formed part of a conscious plan. ${ }^{3}$ Helmold was far from being alone in recognising a connection between the different theatres of war. The Annales Rodenses state that the expeditio was divided into three parts which went on to fight in Lisbon, against the pagan Slavs and in Syria. ${ }^{4}$ The Annales Magdeburgenses, Annales Palidenses and Annales Colonienses maximi also give details of the Christian attacks on Lisbon, the Baltic region and Damascus. ${ }^{5}$ The Casus monasterii Petrihusensis linked the proposed Syrian campaign with the decision to attack the pagan Slavs, known collectively to Western Christians as Wends, as did Otto of Freising. ${ }^{6}$ The De expugnatione Lyxbonensi and the 'Lisbon Letter', as well as the Annales Elmarenses and the Sigeberti Continuatio Valcellensis suggest that the attack on Lisbon had its origins in the preaching for the Syrian campaign. ${ }^{7}$ The Praemonstratensian continuator of Sigebert of Gembloux and Robert of Torigny mention the fighting in the Levant and at Lisbon, Almería and Tortosa. ${ }^{8}$ Henry of Huntingdon contrasted the Christian success in Lisbon with the failure

3 Helmold of Bosau, 'Chronica Slavorum', ed. Heinz Stoob, Ausgewählte Quellen zur deutschen Geschichte des Mittelalters, 19 (Darmstadt, 2008), I.65 (pp. 216-21).

4 'Annales Rodenses', ed. Georg H. Pertz, in MGH SS, 16: 688-723 (here 718).

5 'Annales Magdeburgenses', ed. Georg H. Pertz, in MGH SS, 16: 105-96 (here 188-89); 'Annales Palidenses', ed. Georg H. Pertz, in MGH SS, 16: 48-98 (here 83); 'Annales Colonienses maximi', ed. Karl Pertz, in MGH SS, 17: 729-847 (here 761-63).

6 'Casus Monasterii Petrishusensis', ed. Otto Abel and Ludwig Weiland, in MGH SS, 20: 621-83 (here 674); Otto of Freising, Continued by Rahewin, Gesta Frederici seu rectius Cronica, ed. Franz-Josef Schmale, trans. Adolf Schmidt, 2nd edn (Darmstadt, 1974), I.43 (pp. 210-13) and The Deeds of Frederick Barbarossa, trans. Charles Christopher Mierow (New York, 1953), p. 76.

${ }^{7}$ The Conquest of Lisbon: De expugnatione Lyxbonensi, ed. and trans. Charles Wendell David, with a new foreword and bibliography by Jonathan Phillips (New York, 2001), pp. 68-79; Susan B. Edgington, 'The Lisbon Letter and the Second Crusade', Historical Research 69 (1996), 328-39 (here 336-39); 'Annales Elmarenses', in Les annales de Saint-Pierre de Gand et de Saint-Amand, ed. P. Grierson (Bruxelles, 1937), p. 110; 'Sigeberti Continuatio Valcellensis', ed. Ludwig Konrad Bethmann, in MGH SS, 6: 458-60 (here 459-60). 
of the Syrian expedition and mentioned the Almería campaign. ${ }^{9}$ A contemporary troubadour poem likewise made the connection between the fighting in the Levant and the ChristianMuslim conflict in Iberia. ${ }^{10}$

Whilst Constable concludes that the near simultaneous attacks on the Wends and the Muslims of Iberia and Syria formed part of a general Christian offensive, Alan Forey argues that neither the writings of most of the contemporary chroniclers and annalists, nor those of Eugenius III and Bernard of Clairvaux prove that the crusade was conceived as a concerted Christian attack on three fronts. He adds that most of the sources show little recognition of the conflict in more than one theatre, and concludes that only the Syrian campaign was initially planned. Concerning the Christian assaults in the Baltic region and the attack on Almería by King Alfonso VII of León-Castile, 'Eugenius appears in fact to have been doing no more than agree to the particular schemes which others had devised and to have considered them as meritorious'. Forey's conclusions imply that the other campaigns identified by Constable should not be considered as forming part of the Second Crusade. ${ }^{11}$

It is not surprising that most contemporary commentators were aware of the conflict on only one front. In an age of poor communications, contemporaries could only comment on events and circumstances that came to their immediate attention. Access to news was usually determined by contact with eyewitnesses or written reports, and this depended upon where and when the scribe was writing. Normally such accounts were narrow in scope, being the product of individuals with their own immediate and perhaps regional concerns and interests to relate. A writer would often record only what they considered worthy or significant, or perhaps what their particular audience might like to know. News of events taking place far from the writers' geographical spheres of interest was unlikely to reach them and perhaps was even less likely to be recorded. We should expect most contemporary commentators on the enterprise to show awareness of only one theatre of war. And as we will see below, the actions of Pope Eugenius, Abbot Bernard and the Church authorities in supporting and endorsing the near simultaneous campaigns in Iberia and against the pagan Slavs were indeed reactive. There is no evidence to suggest that pope and abbot initially conceived of a strategy embracing Christian assaults on three fronts.

Nevertheless, as Phillips observes and as we have just seen, commentators easily accommodated the Iberian and Baltic campaigns within the context of the contemporary expedition to the Levant. ${ }^{12}$ That most contemporaries were seemingly aware of the conflict in only one theatre does not mean that the preaching of holy war by Eugenius and Bernard had a negligible impact on that theatre. Nor does it preclude the possibility that such conflict should be considered as forming part of the Second Crusade. These are simple and obvious observations, but they nonetheless provide part of the editors' rationale for the compilation of the present volume. Forey's and indeed Constable's frameworks need not constrain the scholar of Christian holy war in the mid-twelfth century. The historian can consider whether the phenomenal success of the Cistercian call to arms somehow influenced theatres of war that are not traditionally associated with the Second Crusade. Only then can one discern the

8 'Sigeberti Continuatio Praemonstratensis', ed. Ludwig Konrad Bethmann, in MGH SS, 6: 447-56 (here 447, 453-54); Robert of Torigny, 'Chronicon', ed. Ludwig Konrad Bethmann, in MGH SS, 6: $475-535$ (here 497-98).

${ }^{9}$ Henry of Huntingdon, Historia Anglorum, ed. and trans. Diana Greenway (Oxford, 1996), pp. 752-53.

${ }^{10}$ Pierre Bec, La Lyrique française au Moyen Age (XIIe-XIIIe s.), 2 vols (Paris, 1977-78), 2: 86.

11 Alan J. Forey, 'The Second Crusade: Scope and Objectives', Durham University Journal 86 (1994), 165-75 (here 172).

12 Phillips, Second Crusade, p. xxviii. 
potential scope of the enterprise. An introduction to a volume that seeks in part to challenge the largely accepted scope of the Second Crusade must necessarily address this debate at points during its discourse and perhaps even contribute to the discussion.

On Christmas Eve 1144, Zangī, the Muslim ruler of Aleppo and Mosul, seized the Christian-held city of Edessa in Mesopotamia. News of the fall of Edessa and the Latin settlers' appeals for military help probably reached the West by the spring of 1145 . Pope Eugenius III subsequently issued the papal bull Quantum praedecessores on 1 December of that year. Sanctioned by God's representative on earth and specifying the temporal and spiritual privileges for those who decided to take the cross, Quantum praedecessores was initially addressed and first dispatched to the court of King Louis VII of France and his magnates. The bull marked the formal proclamation and legitimisation of a military campaign to defend the Latin Church in the Levant. However, it was the reissue of the bull (with a few small changes) on 1 March 1146 that brought about the formal launch of the expedition at King Louis's Easter court at Vézelay, $1146 .^{13}$

The time lapse between Zangī's capture of Edessa and the issuing of Quantum praedecessores, and the reasons why the Syrian expedition was not formally launched until after the bull was reissued, have been sources of much discussion. John G. Rowe, who represents Eugenius III as a figure much more concerned with the papacy's political problems than the fate of the Latin settlers in the East, suggests that the pope had probably heard of the fall of Edessa by March 1145. He argues that it took an Armenian delegation of churchmen and the arrival in the West in November 1145 of Hugh, bishop of Jabala, to turn the pope's attention away from his Italian preoccupations. Before then the pope failed to consider the security of Outremer. ${ }^{14}$ Odo of Deuil, one of our two main sources on the origins of the Syrian expedition, portrays King Louis VII of France as the sole initiator of the campaign. ${ }^{15}$ Rowe suggests that when Louis first attempted to gather support for an expedition to the Levant at his Christmas court at Bourges in 1145, he probably knew nothing about the existence of Quantum praedecessores. ${ }^{16}$ Certainly, issued at Vetrella on 1 December 1145 , it is unlikely that the bull reached Bourges, some 600 miles away, by Christmas of that year. On the other hand, Aryeh Graboïs's and George Ferzoco's reading of Otto of Freising, the second of our two sources, suggests that the pope actually issued the bull in response to the king's initiative that was first made public at Bourges. ${ }^{17}$ There was indeed contact between the French crown and the curia during the summer and autumn of $1145 .{ }^{18}$ It would appear that the bull was not issued independently of Louis's wishes, but in fact reflected a realisation of his aims. Historians have offered a number of reasons why Louis took the cross. Graboïs argues that

13 Odo of Deuil, De profectione Ludovici VII in orientem. The Journey of Louis VII to the East, ed. and trans. Virginia Gingerick Berry (New York, 1948), pp. 8-9; Letter of 1 December 1145: Eugenius III, 'Epistolae et privilegia', in PL, 180: 1013-1614 (here 1064-66). Letter of 1 March 1146: R. Grosse, 'Überlegungen zum Kreuzzugsaufruf Eugens III. von 1145/46. Mit einer Neuedition von JL 8876', Francia 18 (1991), 85-92. There is a translation based on this document in Phillips, Second Crusade, pp. 280-82.

${ }^{14}$ See John G. Rowe, 'The Origins of the Second Crusade: Pope Eugenius III, Bernard of Clairvaux and Louis VII of France', in The Second Crusade and the Cistercians, ed. Gervers, pp. 80-89 (here pp. 81-84).

15 Odo of Deuil, De profectione Ludovici VII in orientem, p. 6.

${ }^{16}$ Rowe, 'The Origins of the Second Crusade', p. 83.

17 Aryeh Graboïs, 'The Crusade of King Louis VII: A Reconsideration', in Crusade and Settlement: Papers Read at the First Conference of the Society for the Study of the Crusades and the Latin East Presented to R. C. Smail, ed. Peter W. Edbury (Cardiff, 1985), pp. 94-104; George Ferzoco, 'The Origin of the Second Crusade', in The Second Crusade and the Cistercians, ed. Gervers, pp. 91-99 (here pp. 92-93); Otto of Freising, Gesta Frederici, I.36 (pp. 200-1) and The Deeds of Frederick Barbarossa, pp. 70-71.

18 Phillips, Second Crusade, pp. 41-42. 
Bernard of Clairvaux probably convinced Louis to undertake a penitential pilgrimage to Jerusalem to expiate his sin for the king's opposition to the election of Peter of La Châtre to the archbishopric of Bourges in 1141. Louis was placed under interdict for his opposition to Peter until 1144. Graboïs highlights Louis's displays of piety and his apparent lack of interest in worldly matters while en route to the Latin East. He argues that Louis's determination to visit the holy places - and particularly Jerusalem - is a reflexion of the king as a penitential pilgrim, not as an armed warrior who marched east to bring military help to the Latin settlers: 'The crusade of King Louis VII was thus a pilgrimage to Jerusalem'. ${ }^{19}$ Marcus Bull counters this argument, suggesting that prior to embarking for the East, Louis was determined to identify himself with crusading through symbolically charged forms of ritualistic display and association with both Eugenius III and Bernard of Clairvaux. Moreover, far from being detached from secular matters, Louis took the opportunity to express his royal authority while on crusade..$^{20}$ Louis surely wanted to be recognised as both a king and a holy warrior. The development of such a royal persona was central to Capetian 'propaganda' that increasingly sought to associate the burgeoning crusading movement with the legitimacy of the royal dynasty. Phillips adds that Louis seems to have been genuinely affected by the loss of Edessa. He also points out that at Bourges the king demanded that his men follow him to aid their brothers in the East. The pilgrimage to Jerusalem was not at the forefront of his mind. ${ }^{21}$

According to Ferzoco, Louis's initial attempt to launch the expedition at Bourges failed for unspecified 'political reasons'.22 Phillips adds that the magnates at Louis's Christmas court chose to delay their verdict on whether to campaign in the East owing to a mixture of secular and spiritual concerns. He stresses, however, that the absence at Bourges of Quantum praedecessores was probably the deciding factor that compelled Louis's associates to postpone their decision until the Easter meeting at Vézelay. ${ }^{23}$ Rowe suggests that the initial bull probably reached both Louis and Bernard of Clairvaux - whom was to be commissioned with preaching the Syrian campaign - around the middle of January 1146. Both sent replies to Eugenius whom then incorporated their ideas into his March reissue of Quantum praedecessores. $^{24}$

Recent opinion on Eugenius, combined with (and perhaps influenced by) Bernard of Clairvaux's rather disparaging comments concerning the pontiff, tends to give the impression that Eugenius cared little for the fate of the Latin East or at best adopted a rather passive attitude towards the region. ${ }^{25}$ That he spent little time preaching the Syrian campaign in person cannot have helped his reputation. The bulk of the recruitment drive was left to Abbot Bernard of Clairvaux and his trusted Cistercian colleagues.

Eugenius's commission to his fellow Cistercian was in fact an astute choice: Bernard was and still is widely recognised as being the most influential spiritual leader of his time. In the words of Otto of Freising, he was 'endowed with wisdom and knowledge of letters, renowned for signs and miracles'. He was perceived 'as a divine oracle' and was therefore the

${ }^{19}$ Graboïs, 'The Crusade of King Louis VII', pp. 91-99.

${ }^{20}$ Marcus Bull, 'The Capetian Monarchy and the Early Crusade Movement: Hugh of Vermandois and Louis VII', Nottingham Medieval Studies 40 (1996), 25-45.

${ }^{21}$ Phillips, Second Crusade, p. 64.

${ }^{22}$ Ferzoco, 'The Origin of the Second Crusade', p. 94.

23 Phillips, Second Crusade, pp. 61-63.

24 Rowe, 'The Origins of the Second Crusade', p. 84.

25 See, for example, Christopher J. Tyerman, God's War: A New History of the Crusades (Cambridge, Mass., 2006), p. 275; Bernard of Clairvaux, 'Epistolae', in Sancti Bernardi Opera, ed. Jean Leclercq and Henri Rochais, 8 vols (Roma, 1957-77), 8: 113-15 (no. 237); for the translation see The Letters of St. Bernard of Clairvaux, trans. Bruno Scott James, 2nd edn (Stroud, 1998), pp. 385-86 (no. 315). 
perfect recruiting agent for the Syrian expedition. ${ }^{26}$ The pope pointed out that he himself was unable to preach the campaign in person because of his political problems with the Roman citizens. ${ }^{27}$ However, he sent missives to England, the town of Tournai and to Count Thierry of Flanders, and it is likely that Quantum praedecessores formed part of this communication. ${ }^{28}$ He appointed a plethora of papal legates with the undoubted hope of providing the holy warriors with both temporal and spiritual support. ${ }^{29}$ In addition, he attempted to facilitate the progress of the Syrian expedition by communicating with the kings of Sicily and Hungary, and the Byzantine emperor. ${ }^{30}$ These are not exactly the passive acts of an uncaring pontiff.

Phillips has worked hard to rehabilitate Eugenius's reputation, and most significantly, he has demonstrated that Eugenius and the curia must have been very anxious about the fate of the Latin East during the latter half of 1145. In the decades following the capture of Jerusalem in 1099, chroniclers continued to emphasise the divine approval of the First Crusade, the bravery and honour of the First Crusaders and the special spiritual significance of the Holy City. Through a lengthy exposition of Quantum praedecessores, Phillips highlights a number of themes that are repeated throughout the bull and that exploited the remarkable legacy of the First Crusade: the precedent of Pope Urban II and the First Crusade; the idea of sons imitating and augmenting the heroic deeds of their forbears; the offer of the remission of sins; the need to help the Eastern Church; the idea that Eugenius acted with divine authority; and an appeal to his audience's sense of knightly honour. Each of these themes was chosen carefully in order to resonate with his warrior audience. The response to the preaching of the Syrian campaign was remarkable. Given that Quantum praedecessores should have accompanied every official crusade sermon, it was evidently a well-researched and expertly crafted piece for which 'Eugenius himself, along with his cardinals and colleagues' must take credit. ${ }^{31}$ Rudolf Hiestand adds that Eugenius stayed north of the Alps between March 1147 and May 1148, and argues that once the pope had launched the Syrian campaign he saw it as his duty to contribute to the stability and order in the French and imperial realms. ${ }^{32}$

At King Louis's Easter court at Vézelay, 1146, Bernard of Clairvaux give his famous crusade sermon and the king, his wife Eleanor of Aquitaine and at least twenty-four other great magnates as well as many of the watching crowd took the cross. ${ }^{33}$ Bernard then issued a standard letter, tailored to meet individual circumstances, and intended to be read out in conjunction with Quantum praedecessores by either designated preachers or local clergy. ${ }^{34}$

${ }^{26}$ Otto of Freising, Gesta Frederici, I.36 (pp. 200-1) and The Deeds of Frederick Barbarossa, pp. 70-71.

27 Odo of Deuil, De profectione Ludovici VII in orientem, pp. 8-9.

28 'Hisoriae Tornacenses partim ex Herimanni libris excerptae', ed. Georg Waitz, in MGH SS, 14: 327-52 (here 345); 'Historia gloriosi regis Ludovici VII, filii Ludovici grossi', in Recueil des Historiens des Gaules et de la France, ed. Martin Bouquet and others, 24 vols (Paris, 1738-1904), 12: 124-33 (here 126); Eugenius to the bishop of Salisbury, in Regesta pontificum Romanorum, ed. Philip Jaffé and others, 2nd edn, 2 vols (Leipzig, 1885-88), 2: 36 (no. 8959).

${ }^{29}$ Constable, 'The Second Crusade as Seen by Contemporaries', pp. 263-65.

${ }^{30}$ Rudolf Hiestand, 'The Papacy and the Second Crusade', in Second Crusade, ed. Phillips and Hoch, pp. 32-53 (here p. 44).

${ }^{31}$ Phillips, Second Crusade, pp. 17-60. Quotation at p. 50.

${ }^{32}$ Hiestand, 'The Papacy and the Second Crusade', pp. 40-43.

33 'Historia gloriosi regis Ludovici VII', pp. 125-27.

34 On Bernard's crusading letters see: Peter Rassow, 'Die Kanzlei St. Bernhards von Clairvaux', Studien und Mitteilungen zur Geschichte des Benediktinerordens 34 (1913), 243-79; Jean Leclercq, 'L'encyclique de saint Bernard en faveur de la croisade', Revue bénédictine 81 (1971), 282-308; Etienne Delaruelle, 'L’idée de croisade chez saint Bernard', in Mélanges saint Bernard: XXIVe Congrès de l'Association bourguignonne des 
The abbot's extant correspondence preaching the campaign to the Levant is addressed to the archbishops of 'Eastern Francia' (the central Rhineland) and Bavaria, Arnold, archbishop of Cologne, Manfredo, bishop of Brescia, the Knights Hospitaller and the duke, magnates and people of Bohemia. ${ }^{35}$ Bernard's secretary, Nicholas of Clairvaux, also addressed a similar letter to the count and nobles of Brittany in which he announced the forthcoming visit of Geoffrey of Lèves, bishop of Chartres, to preach for the expedition. ${ }^{36}$ Bernard also instructed Abbot Reynald of Morimond to preach at Bassingy and there is some evidence to suggest that Gerlach, abbot of Rein, was asked to preach in Carinthia and Styria. ${ }^{37}$

The message of Eugenius and Bernard and the supposed propagation of a new, transcendental concept of the crusade indulgence providing absolution from divine punishments for sin, independent from ecclesiastically imposed penance, have long been discussed. Constable, Ersnt-Dieter Hehl and Hans Eberhard Mayer are amongst those who argue that Eugenius's offer of the remission of sins marked a significant advance in crusade theology. They state that Pope Urban II only promised the First Crusaders the remission of the specific penitential punishments enjoined by the Church. Eugenius is thought to have also offered absolution from temporal (that is, divine) punishments for sin inflicted by God in this world and the next. Mayer follows Jonathan Riley-Smith in suggesting that Eugenius's formulation reflected the popular reinterpretation of Urban's original promise. After Urban's sermon at Clermont in 1095, preachers and would-be crusaders blurred any distinction between the remission of penance and the remission of sins. ${ }^{38}$

In her contribution to the present volume, Ane Bysted points out that the actual theology of penance as propagated by the clerical elite in the mid-twelfth century, and the relation between the act of penance and the remission and forgiveness of sins, is in fact unclear. Therefore, current suggestions that Eugenius's offer of the remission of sins marked a significant advance in crusading theology remain hypotheses until further work is completed on the theology of penance in the late eleventh and mid-twelfth centuries. Bysted suggests that the most influential development in crusade theology at this time was Bernard of Clairvaux's preaching of the campaign as a time of jubilee. This notion seemingly solved one of the more disturbing ambiguities in contemporary theology by stressing God's mercy as the motivating force to take up arms. Bernard's letters therefore circumvented the popular but

Sociétés savantes (8e Centenaire de la mort de saint Bernard), Dijon, 1953 (Dijon, 1954), pp. 53-67.

35 Bernard of Clairvaux, 'Epistolae', pp. 311-17 (no. 363) and The Letters of St. Bernard of Clairvaux, pp. 460-63 (no. 391); J. Groven, 'Die Kölnfahrt Bernhards von Clairvaux', Annalen des Historischen Vereins für den Niederrhein 120 (1932), 1-48 (here 44-48); Caesare Baronius, Annales ecclesiastici Caesaris Baronii, cura Oderici Raynaldi et Jacobi Laderchii, et ad nostra usque tempora perducti ab Augustino Theiner, 37 vols (Bar-le-Duc, 1864-83), 18: 646-47; Jean Leclercq, 'Un document sur S. Bernard et la Seconde Croisade', Revue Mabillon 43 (1953), 1-4; Bernard of Clairvaux, 'Epistolae', pp. 434-37 (no. 458) and The Letters of St. Bernard of Clairvaux, pp. 463-64 (no. 392).

${ }^{36}$ Nicholas of Clairvaux, 'Epistolae', in PL, 182: 671-72.

37 Leopold Grill, 'Der hl. Bernhard von Clairvaux und Morimond, die Mutterabei der österreichischen Cistercienserklöster', in Festschrift zum 800 Jahrgedächtnis des Todes Bernhards von Clairvaux (Wien, 1953), pp. 31-118 (here pp. 102-3); Eugene Willems, 'Cîteaux et la seconde croisade', Revue d'histoire ecclésiastique 49 (1954), 116-51 (here p. 135).

38 For example: Adolf Gottlob, Kreuzablaß und Almosenablaß. Eine Studie über die Frühzeit des Ablaßwesens (Stuttgart, 1906), pp. 105-13; Valmar Cramer, 'Kreuzpredigt und Kreuzugsgedanke von Bernhard von Clairvaux bis Humbert von Romans', in Das Heilige Land in Vergangenheit und Gegenwart, ed. Valmar Cramer and Gustav Meinertz, 5 vols (Köln, 1939-50), 1: 43-204 (here 48-53); Constable, 'The Second Crusade as Seen by Contemporaries', p. 249; Ernst-Dieter Hehl, Kirche und Krieg im 12. Jahrhundert: Studien zu kanonischem Recht und politischer Wirklichkeit (Stuttgart, 1980), pp. 127-28; Hans Eberhard Mayer, The Crusades, 2nd edn (Oxford, 1988), pp. 23-37, 293-95; Jonathan Riley-Smith, The First Crusade and the Idea of Crusading (London, 1986), pp. 27-29. 
theologically unsound notion that campaigning against the enemies of Christ could be an act of self-salvation. William Purkis suggests that the Cistercians developed crusading theology in one further area. Neither Eugenius nor Bernard attempted to inculcate the Second Crusaders with the ideas of Christomimesis that were central to Pope Urban II's preaching for the First Crusade. According to Purkis, Bernard believed that only those individuals who devoted their whole life to the religious profession could truly pursue imitatio Christi; hence, the Cistercians' call to would-be crusaders to imitate instead the heroic deeds of their forbears in the Holy Land. ${ }^{39}$

In the summer of 1146, Bernard of Clairvaux began his legendary seven-month preaching tour of the Low Countries and parts of the Holy Roman empire. ${ }^{40}$ In the meantime, during the month of October, Pope Eugenius III issued a second bull, Divina dispensatione (I), to the people and churchmen of the imperial lands in northern Italy. Although lacking the narrative details of Quantum praedecessores, the bull likewise set out the spiritual and temporal privileges for following Louis VII's example and embarking on such a holy labour. ${ }^{41}$ The abbot eventually met with the emperor-elect, King Conrad III of Germany, around midNovember at the king's court in Frankfurt am Main. Conrad did not take the cross at this point, but when again in the presence of Bernard of Clairvaux at the Christmas court in Speyer, the king and his nephew, Frederick of Swabia, as well many other princes and illustrious men did indeed take the cross. ${ }^{42}$

The origins and impetus behind Conrad's recruitment for the campaign to the Levant are a matter of some debate. The traditional view, first posited by Harald Cosack, is that Bernard of Clairvaux essentially badgered an unwilling Conrad into joining the Syrian expedition. ${ }^{43}$ Convention has it that the king was averse to taking the cross at his Frankfurt am Main court in November, and that his reluctance continued at Speyer until he was overcome by an electrifying Bernardine sermon. Moreover, Bernard's recruitment of Conrad was unauthorised. Pope Eugenius disapproved of the emperor-elect's involvement in the campaign as he had hoped that Conrad would provide him with protection from the radical Roman commune and King Roger II of Sicily. The grounds for this argument are found in a letter from Conrad to Eugenius datable to March 1147 that refers to a lost letter of the pope. ${ }^{44}$ Crucially, Conrad writes that he took the cross 'without your [Eugenius's] knowledge', which led Graham Loud to conclude that the curia had not planned on Conrad joining the expedition. ${ }^{45}$

In his article 'Papacy, Empire, and the Second Crusade' (2001), Phillips interprets Conrad's letter differently: he reads it as an apology to Eugenius for the king's failure to delay his preparations for embarking on campaign as the pope seemed to have advised. He also

${ }^{39}$ William J. Purkis, Crusading Spirituality in the Holy Land and Iberia, c. 1095-c. 1187 (Woodbridge, 2008), pp. 86-119.

40 J. Pitra, 'De itinere S. Bernardi', in PL, 185: 1823-24; 'Vita prima S. Bernardi', in PL, 186: 373-99.

${ }^{41}$ Papsturkunden für Kirchen im Heiligen Lande, ed. Rudolf Hiestand (Göttingen, 1985), no. 63, pp. 19395.

42 'Vita prima S. Bernardi', in PL, 186: 381-83.

${ }^{43}$ Harald Cosack, 'Konrads III. Entschluß zum Kreuzzug', Mitteilungen des Instituts für Österreichische Geschichtsforschung 35 (1914), 278-96.

44 Die Urkunden Konrads III. und seines Sohnes Heinrich, ed. Friedrich Hausmann, MGH Diplomata regum et imperatorum Germaniae, 9 (Wien, 1969), 332-33. A translation by Graham A. Loud of this important letter can be found in The Crusades: An Encyclopedia, ed. Alan V. Murray, 4 vols (Santa Barbara, 2006), 4: 1298.

45 Graham A. Loud, 'Some Reflections on the Failure of the Second Crusade', Crusades 4 (2005), 1-14 (here 3-6). 
argues that pertinent details in Conrad's letter are ambiguous; it is very positive in tone; and there is no mention of Eugenius's fear of Roger II or the Roman commune. He points out that Eugenius's predecessor, Lucius II, had signed a seven-year truce with Roger II and admittedly with the benefit of hindsight - we know that peace was maintained between the pontiff and Roger. ${ }^{46}$ In his recent monograph on the Second Crusade, Phillips argues that Conrad was simply stating a fact when he wrote to Eugenius asserting that he had taken the cross without the pope's knowledge. He adds that Eugenius could not have been surprised at this news, given that Bernard had been preaching in the empire since the previous October. ${ }^{47}$ Perhaps it is worth highlighting that Bernard was unlikely to recruit the emperor-elect without papal authority: the abbot was well known for his obedience and observance of the right order of things. In any case, Bernard had a papal mandate to preach the holy enterprise.

In a letter written while on campaign, the king actually states that he had set out after receiving advice and encouragement from both Bernard and Eugenius. ${ }^{48}$ The only surviving papal letter on the subject of Conrad's participation in the Syrian expedition is positive. The appearance of five papal legates in the German imperial lands during 1147 is a reflection of the pontiff's commitment to Conrad's campaign. The Cistercians conceived of the relationship between the papacy and empire as that of the ecclesiastical and secular swords working in partnership to advance the cause of Christianity. ${ }^{49}$ When combined with Conrad's experience, influence and relations as ruler-elect of the Holy Roman empire, such a conception may have predisposed the papacy to involve Conrad and the powerful and wealthy German nobility in the holy enterprise. The emperor-elect's recruitment was indeed logical: Phillips points out that there was a German tradition of pilgrimage, holy war and crusading, and that Conrad had already demonstrated his commitment to the Holy Land when he travelled to Jerusalem in 1124. Given that many nobles from the empire would respond to Eugenius's and Bernard's offer of the remission of sins, who better to lead them on campaign than Conrad III? ${ }^{50}$

That Conrad did not commit himself to the expedition at Frankfurt am Main in November 1146 is explicable. The empire was in a state of political disorder. The king had to consider the potential political problems that might arise in his absence while on campaign and to plan contingencies should he fail to return. No major monarch had yet been on crusade and the risks at home and abroad were immense. As Phillips suggests, an announcement of Conrad's commitment to the crusade at Speyer in December would have given Conrad and Bernard more time to resolve existing and potential political problems. The Christmas court would also have been a well-attended, appropriate occasion for officially launching royal involvement in the expedition. ${ }^{51}$ Christopher Tyerman takes this further by suggesting that Bernard's presence at both Frankfurt am Main and Speyer formed part of a well-orchestrated piece of recruiting theatre. He adds that it is inconceivable that the combined German force would have been ready to leave for the East in May 1147 unless Conrad's position as nominal head of the army was known and accepted long before the king's courts. Tyerman does not explain what was to be gained by turning down Bernard's offer of the cross at Frankfurt am Main. But at Speyer, 'Conrad fulfilled the ceremonial fiction of sudden conversation' when he

\footnotetext{
46 Jonathan Phillips, 'Papacy, Empire and the Second Crusade', in Second Crusade, ed. Phillips and Hoch, pp. 15-31.

${ }^{47}$ Phillips, Second Crusade, pp. 87-96, 129-31.

${ }^{48}$ Die Urkunden Konrads III., p. 358.

49 Ian S. Robinson, The Papacy, 1073-1198. Continuity and Innovation (Cambridge, 1990), pp. 455-58.

${ }^{50}$ Phillips, Second Crusade, pp. 88-93.

${ }^{51}$ Phillips, Second Crusade, pp. 93-94.
} 
received the cross and a holy banner from the hands of the abbot which had been placed conveniently nearby. Tyerman suggests that participation in the campaign would have been viewed as a practical demonstration of the reach of German imperial power. ${ }^{52}$

By the end of the Regensburg diet in February 1147, where Abbot Adam of Ebrach read aloud the letters of Eugenius and Bernard, many members of the empire's secular and ecclesiastical nobility, including bishops Henry of Regensburg, Otto of Freising and Reginbert of Passau, as well as Vladislav, duke of Bohemia, Ottokar, margrave of Styria and Welf VI, younger brother of the dispossessed former duke of Bavaria, Henry X, had all assumed the cross. ${ }^{53}$

Gathering at Regensburg in late May 1147, the forces headed by Conrad III either walked beside or navigated along the Danube before passing through Hungary and then the Byzantine empire. It is traditionally held that an exceptionally undisciplined German army posed a significant threat to the security of the empire's capital, Constantinople, and consequently Conrad's relations with the Byzantine emperor, Manuel I Komnenos, were severely strained. These conventional notions stem from the works of Kugler, Ferdinand Chalandon and Steven Runciman and they remain highly influential. Jonathan Harris, for example, has argued recently that the Germans posed a real threat to the empire and that the behaviour of the German army caused Manuel Komnenos to treat Conrad and the German forces with enmity. ${ }^{54}$ Jason T. Roche's contribution to the present volume analyses the Greek sources relating to the passage of the German army through the empire. His work sheds light on the neglected influence of the contemporary Greek encomiastic tradition on the wellknown Greek narratives of the Second Crusade. Roche advises extreme caution before following convention and accepting the source portrayals of excessive German indiscipline and belligerence in the empire and of poor relations between the Staufer and the Komnenoi.

Conrad's experiences in Anatolia and the reasons for the failure of the campaign in Asia Minor have also received attention recently. Conor Kostick, for example, restating the position of Kugler and others who have followed him, believes that Conrad's army was unusually undisciplined and poorly organised. The army was thus in effect the agent of its own downfall in its encounters with the Anatolian Turks. ${ }^{55}$ The idea that indiscipline or 'social unrest' was somehow responsible for the failure of the crusade in Anatolia remains unproven. Loud wonders whether the armies of the Second Crusade were any more disorderly or poorly led than those of other medieval expeditions.$^{56}$ Roche has recently demonstrated that the retinues accompanying Conrad were not extraordinarily undisciplined. Nor did the leading contingents display unusual levels of disorganisation and indiscipline during their clashes with the Turks. The warriors did not have the tactical expertise to defeat or even defend themselves against an enemy who employed tactics with which the Christians were largely unfamiliar. ${ }^{57}$

52 Tyerman, God's War, pp. 286-88, 292-94.

${ }^{53}$ Otto of Freising, Gesta Frederici, I.43 (pp. 210-11) and The Deeds of Frederick Barbarossa, pp. 75-76.

${ }^{54}$ Kugler, Studien zur Geschichte des Zweiten Kreuzzugs, pp. 119-32; Ferdinand Chalandon, Jean II Comnène (1118-1143) et Manuel I Comnène (1143-1143), 2 vols (Paris, 1912), 2: 263-81, 286-88; Steven Runciman, A History of the Crusades, 3 vols (Cambridge, 1951-1954), 2: 260-63, 266-68, 274-75; Jonathan Harris, Byzantium and the Crusades (London, 2003), pp. 95-96.

${ }^{55}$ Kugler, Studien zur Geschichte des Zweiten Kreuzzugs, pp. 148-56; Conor Kostick, 'Social Unrest and the Failure of Conrad III's March through Anatolia, 1147', German History 28 (2010), 125-42.

${ }^{56}$ Loud, 'Some Reflections on the Failure of the Second Crusade', p. 3.

57 Jason T. Roche, 'Conrad III and the Second Crusade in the Byzantine Empire and Anatolia, 1147' (unpublished Ph.D. thesis, University of St Andrews, 2008), pp. 221-28. 
A number of contemporary sources suggest that Byzantine perfidy, in particular, that of Manuel Komnenos, was to blame for the collapse of the campaigns of both Conrad III and King Louis VII of France in Anatolia. ${ }^{58}$ Chalandon was the first to consider that perhaps Manuel could be excused for causing the failure of the expeditions, as a successful campaign in the Levant would have challenged his imperial dignity and Byzantine interests in northern Syria. ${ }^{59}$ Runciman went further than Chalandon in stating that Manuel may have actually condoned Turkish attacks on the Christian warriors in order to maintain a truce with the Seljuks of Anatolia, arguing that such a truce was important to Manuel's foreign policy towards the Latin principality of Antioch. ${ }^{60}$ Ralph-Johannes Lilie follows a similar line, suggesting that Manuel's supposed attitude towards the crusaders is indeed explicable in terms of imperial policy. He refrains from explicitly stating that Manuel encouraged Turkish attacks on the Christian warriors, but the accusation is certainly implied with regard to the assaults on the French army. ${ }^{61}$ This theory has since hardened into a complete negative. Phillips maintains that Manuel Komnenos did indeed incite the Turks to attack the French warriors, and Harris believes that he encouraged them to attack both the French and German armies. ${ }^{62}$ Such allegations are found in the contemporaneous Latin sources, although it is the charge of Byzantine duplicity offered by the Greek historian, Niketas Choniates, that historians cite as the most compelling evidence. ${ }^{63}$ Roche has demonstrated the utter unreliability of Choniates as a source for the Second Crusade in Anatolia. Concerning the German expedition, he also suggests that Latin accusations of Byzantine perfidy are a reflection of the crusaders' ignorance of the topography of Anatolia and its fragile geopolitical situation. There was actually very little that the Byzantine emperor could have done to alter the fate of the German force once it had crossed the Bosphoros. ${ }^{64}$

Amadeus III, count of Maurienne, led a crusader force through Italy en route to Constantinople. After crossing from Brindisi to Dyrrachion, he joined up with the army of King Louis VII of France at the Byzantine capital late in 1147. Louis's army had advanced through France and Germany to Regensburg. It then followed Conrad along the Danube and into Hungary, before crossing into the western part of the Byzantine empire. After suffering losses through starvation and Turkish attacks in Anatolia, the remnants of the forces of Louis VII and Amadeus III travelled by ship to the Levant and arrived at Antioch in March 1148 .

The prince of Antioch, Raymond of Poitiers, had courted the French king in anticipation of his help in strengthening the prince's power in northern Syria. Raymond hoped to subjugate a number of neighbouring cities including Aleppo, the centre of Zangīd power.

58 See, for example, A. S. Tritton, 'The First and Second Crusades from an Anonymous Syriac Chronicle', Journal of the Royal Asiatic Society of Great Britain and Ireland 92 (1933), 69-102, 273-306 (here 298); Michael the Syrian, 'Chronicle', ed. and trans. Jean-Baptiste Chabot, in Chronique de Michel le Syrien, Patriarche Jacobite d'Antioche (1166-1199), 4 vols (Paris, 1899-1910), 3: 275.

${ }^{59}$ Chalandon, Jean II Comnène, 2: 263-68, 286-88.

${ }^{60}$ Runciman, A History of the Crusades, 2: 266, 274-76.

${ }^{61}$ Ralph-Johannes Lilie, Byzantium and the Crusader States, 1096-1204, trans. J. C. Morris and Jean E. Ridings

(Oxford, 1993), pp. 158-62.

${ }^{62}$ Harris, Byzantium and the Crusades, pp. 96-100; Phillips, Second Crusade, pp. 181-82, 205-06.

63 Niketas Choniates, O City of Byzantium, Annals of Niketas Choniates, trans. Harry J. Magoulias (Detroit, 1984), p. 39.

64 Jason T. Roche, 'Niketas Choniates as a Source for the Second Crusade in Anatolia', in Prof. Dr. Işın Demirkent Anisina, ed. Ebru Altan and others (İstanbul, 2008), pp. 379-88 and 'Conrad III and the Second Crusade', pp. 162-220. 
After spending three months recuperating in the region, Louis VII declined the prince's proposals and instead headed south toward the kingdom of Jerusalem. The alleged affair between Raymond and his niece, the king's wife, Eleanor of Aquitaine, is often cited as a reason for Louis's refusal to help Antioch. Contemporary rumours certainly suggested there was an incestuous liaison between Eleanor and Raymond; such rumours could only have disinclined Louis to help the prince. ${ }^{65}$ Graboïs argues that the king had little interest in campaigning in northern Syria or indeed in recovering Edessa, since his priority was the accomplishment of his pilgrimage to Jerusalem. ${ }^{66}$ Mayer points out that the native Christian population of Edessa was slaughtered, enslaved or exiled following the failed uprising which attempted to recover the city in October $1146 .{ }^{67}$ Martin Hoch adds that the city was pillaged and razed. ${ }^{68}$ There was thus little point in recovering Edessa, the loss of which was the initial casus belli. By extension, Louis may have felt there was less need to attack Aleppo as an indirect means of regaining Edessa. Phillips points out that the prince of Antioch was a vassal of Manuel I Komnenos and that the French crusaders blamed the emperor for their various problems in the Byzantine empire and Anatolia. In theory, any extension of Antiochene power was in effect an extension of Byzantine influence in the Levant, and this was something that the king and his advisors would not countenance. ${ }^{69}$

The wishes and concerns of King Conrad III of Germany and the Jerusalemite nobility must also be taken into consideration when discussing Louis's decision to march south. Having recuperated at the Byzantine court from his ordeals in Anatolia, Conrad arrived by ship at Acre in April 1148. Louis of course was still in the north at this point recovering from his own troubles in the peninsula. Otto of Freising indicates that the German king subsequently made an agreement with King Baldwin III of Jerusalem, Patriarch Fulcher of Jerusalem and the Templars to lead an army against Damascus in the following July. ${ }^{70}$ It would appear that Conrad was made aware of the hopeless situation in Edessa and had been convinced that an attack on Damascus was in the best interests of the settlers in Outremer. William of Tyre confirms that the Jerusalemite nobility hoped the crusaders would offer them military assistance in taking a neighbouring Muslim city. He adds that Patriarch Fulcher was sent to Louis, who was at that time residing in Tripoli, to convince the king to continue south to Jerusalem. ${ }^{71}$ Perhaps it is not surprising that Louis chose to march south with his weakened army and looked to join forces with Conrad and the Jerusalemite barons, given that they had already agreed to attack Damascus. Surely Louis must have also considered that assisting the kingdom of Jerusalem (while taking the opportunity of visiting its holy places) would be of most benefit to Latin Christendom, especially given his likely concerns with fighting in northern Syria.

Loud suggests that the great assembly of crusaders and Latin settlers that convened in the town of Palmarea near Acre on 24 June 1148 gathered merely to confirm the decision to

${ }^{65}$ As Phillips points out, the literature referring to this supposed affair is extensive. See his Second Crusade, p. 319, n. 18.

${ }^{66}$ Graboiis, 'The Crusade of King Louis VII', p. 99.

${ }^{67}$ Mayer, The Crusades, p. 105.

${ }^{68}$ Martin Hoch, 'The Choice of Damascus as the Objective of the Second Crusade: A Re-evaluation', in Autour de la Premiére Croisade: Actes du Colloque de la Society for the Study of the Crusades and the Latin East, Clermont-Ferrand, 22-25 juin 1995, ed. Michel Balard (Paris, 1996), pp. 359-69 (here pp. 362-63).

${ }^{69}$ Jonathan Phillips, Defenders of the Holy Land: Relations between the Latin East and the West, 1119 1187, (Oxford, 1996), pp. 95-96.

${ }^{70}$ Otto of Freising, Gesta Frederici, I.64 (pp. 264-65) and The Deeds of Frederick Barbarossa, pp. 10203.

${ }^{71}$ William of Tyre, Chronique, ed. R. B. C. Huygens (Turnhout, 1986), pp. 756-57. 
attack Damascus. ${ }^{72}$ Phillips posits that there may have been a need to give King Louis VII the opportunity to register his opinion in a formal settlement. ${ }^{73}$ Hoch points out that for the Jerusalemite nobility, informal agreements such as the one seemingly made earlier to attack Damascus, had to be formally agreed before a campaign could be launched on foreign territory. ${ }^{74}$ The decision to attack Damascus has also received scholarly attention. Following Runciman, Mayer argues that the plan to attack the city was ill conceived: its subsequent failure made an enemy of a city that had been allied with Jerusalem since 1140. Hoch has since offered a number of reasons why Damascus was chosen as a target. Perhaps most contentiously, he argues that there had been a complete realignment in Muslim power in Syria in the years immediately preceding the council at Palmarea, the chief and pertinent product of which was an alliance between Damascus and Aleppo made in the spring of 1147. This agreement is said to have essentially rendered obsolete the former alliance between Damascus and the kingdom of Jerusalem. And in any case, that alliance was made in a specific strategic situation in 1140, and should not be viewed as an unconditional long-term agreement. If Hoch is correct, the Damascene-Aleppan alliance posed a significant threat to the security of the kingdom at the time of the council at Palmarea. The allied force of crusaders and Palestinian barons therefore decided to attack Damascus. ${ }^{75}$ The unsuccessful siege of Damascus was lifted within days and its failure has received a great deal of attention. The older historiography tends to follow the original sources closely, ascribing a seemingly doomed decision to move camp outside the Damascene walls to the self-seeking desires of various groups and individuals. More recently, historians have argued that the subsequent retreat occurred owing to tactical failings. Forey and Phillips, for example, suggest that the allies gambled on storming the city but met with stiffer resistance than was expected. Lacking the supplies and the machines to conduct a longer siege, and perhaps most importantly, faced with the imminent threat of confronting a Muslim relief army, the decision was made to change the point of attack to a supposedly weaker section of the city's walls. The allies were compelled to retreat when once again the city walls looked as if they would withstand a brief siege. ${ }^{76}$

In her contribution to the present volume, Deborah Gerish points out there is no extant eyewitness record of the lead up to and occurrence of these events produced by a European immigrant or descendant living in the Levant. ${ }^{77}$ This makes her study of royal identity in the kingdom of Jerusalem around the time of the Second Crusade a potentially troublesome task. Gerish suggests, however, that a largely ignored text composed on the eve of the events of

72 William of Tyre, Chronique, pp. 760-61; Loud, 'Some Reflections on the Failure of the Second Crusade', p. 13.

73 Phillips, Second Crusade, pp. 216-17.

${ }^{74}$ Hoch, 'The Choice of Damascus', p. 367.

75 Runciman, A History of the Crusades, 2: 281; Mayer, The Crusades, pp. 106-7; Hoch, 'The Choice of Damascus', pp. 359-69. Although see note 6 in Suleiman Mourad and James Lindsay's contribution to the present volume.

${ }^{76}$ Kugler, Studien zur Geschichte des Zweiten Kreuzzugs, pp. 194-201; Runciman, A History of the Crusades, 2: 281-85; Alan J. Forey, 'The Failure of the Siege of Damascus', Journal of Medieval History 10 (1984), 13-23; Jan Paul Niederkorn, 'Traditio, a quibus minime cavimus. Ermittlungen gegen König Balduin III. von Jerusalem, den Patriarchen Fulcher und den Templerorden wegen Verrats bei der Belagerung von Damaskus (1148)', Mitteilungen des Instituts für Österreichische Geschichtsforschung 95 (1987), 53-68; Phillips, Second Crusade, pp. 218-26.

${ }^{77}$ William of Tyre was in Europe during 1148. See Peter W. Edbury and John G. Rowe, William of Tyre: Historian of the Latin East (Cambridge, 1988), p. 15. Nevertheless, William states that he received his information on the Palmarea assembly and the Damascus campaign according to the uniform assertions of men who took part in the expedition: William of Tyre, Chronique, p. 742. 
1148 but covering the period 1099 to 1123 reflects the contemporary concerns of the young Baldwin III and his mother Melisende, the queen regnant.

Scholars have suggested that the failure of the siege of Damascus helped propagate the Levantine Muslim jihad or so-called 'counter crusade'. ${ }^{78}$ The formation and effects of contemporary jihad ideology is a topical field of study currently receiving due attention. ${ }^{79}$ Suleiman Mourad and James Lindsay contribute to the present discussions in the current volume through analysis of the writings of Ibn 'Asākir. ${ }^{80}$ They suggest that the Damascene scholar was motivated to disseminate jihad ideology during the rule (and at the behest) of his patron, sultan Nūr al-Dīn, as a result of the Christian attack on his home town in 1148.

Having achieved nothing of note in the region, Conrad III left the Levant in September 1148 and Louis VII departed during the following April. Up until now, it was thought that this was the effective end of the activity of the Second Crusade in Outremer. Janus Møller Jensen's contribution to the present volume suggests that a belated expedition to the Holy Land in 1151, led by the earl of Orkney, Rognval Kale Kolsson, and the Norwegian noble, Erling Ormsson Skakke, set sail in response to preaching in support of the Syrian campaign. As Jensen points out, however, there are no extant references of preaching for the campaign either in Scandinavia (outside of Denmark) or the Scandinavian settlements of the North Atlantic. Indeed, there exists only one oblique reference to a (leading) member of this expedition having assumed the cross. ${ }^{81}$ Nevertheless, it is clear that contemporary notions of Christian holy war infused with the ideals, ambitions and obligations of the Scandinavian warrior elite in the first half of the twelfth century. This dovetailing of ideology, Jensen contends, ensured that Jarl Rognval and Erling Skakke were willing recipients of the message of Eugenius III and Bernard of Clairvaux.

As we saw at the beginning of this introduction, the Second Crusade was also directed towards targets outside the Levant. At the Council of Frankfurt am Main held in March 1147, Bernard of Clairvaux seems to have verbally sanctioned an extension in the geographical scope of the crusade. Saxon nobles declined Bernard's invitation to campaign in the East, justifying their decision by referring to the idolatrous activities of the neighbouring pagan Wends. Bernard subsequently promised the Frankfurt am Main audience the same spiritual privileges for fighting the Wends as those offered to warriors who vowed to campaign in Outremer. Whether it was the Saxon nobles or Bernard of Clairvaux who first mooted the

78 Aharon Ben-Ami, Social Change in a Hostile Environment: The Crusaders' Kingdom of Jerusalem (Princeton, N.J., 1969), p. 79; Meron Benvenisti, The Crusaders in the Holy Land (New York, 1970), pp. 6, 150; Yasser Tabbaa, 'Monuments with a Message: Propagation of Jihad under Nur al-Din (1146-1174)', in The Meeting of Two Worlds: Cultural Exchange between East and West during the Period of the Crusades, ed. Vladimir P. Goss (Kalamazoo, Mich., 1986), pp. 223-40 (here pp. 224-25); Yaacov Lev, 'The Jihad of Sultan Nur al-Din of Syria (1146-1174): History and Discourse', Jerusalem Studies in Arabic and Islam 35 (2008), 227-84.

${ }^{79}$ For example, Nikita Elisséeff, 'The Reaction of the Syrian Muslims after the Foundation of the First Latin Kingdom of Jerusalem', in Crusaders and Muslims in Twelfth-Century Syria, ed. Maya Shatzmiller (Leiden, 1993), pp. 162-72; Niall Christie, 'Motivating Listeners in the Kitab al-Jihad of 'Ali ibn Tahir alSulami (d. 1106)', Crusades 6 (2007), 1-14; Niall Christie and Deborah Gerish, Preaching Holy War: Jihad and Crusade, 1095-1105 (Aldershot, 2009); Suleiman A. Mourad and James E. Lindsay, The Intensification and Reorientation of Sunni Jihad Ideology in the Crusader Period: Ibn 'Asākir (1105-1176) of Damascus and His Age; with an Edition and Translation of Ibn 'Asākir's 'The Forty Hadiths for Inciting Jihad' (Leiden, 2013).

80 Also see Suleiman A. Mourad and James E. Lindsay's 'Rescuing Syria from the Infidels: The Contribution of Ibn 'Asākir of Damascus to the Jihad Campaign of Sultan Nur al-Din', Crusades 6 (2007), 3755.

81 Orkneyinga Saga: The History of the Earls of Orkney, trans. Hermann Pálsson and Paul Edwards (Penguin, 1981), p. 179. 
extension of spiritual privileges to those wanting to fight the Wends is unclear, but one way or another, Bernard wholly supported the decisions made by the Saxon nobles, and a number of them then took the cross at Frankfurt am Main after vowing to campaign against their pagan neighbours. ${ }^{82}$

Pope Eugenius III reacted quickly to the initiative taken at Frankfurt am Main by issuing a third bull on 11 or 13 April. Divina dispensatione (II) effectively sanctioned the campaign to the southern Baltic region while mentioning the original expedition planned to liberate the Church in the Latin East and referring to the Christian-Muslim conflict in the Iberian Peninsula. ${ }^{83}$ Individuals in northern Germany, Denmark and Poland promptly responded to Bernard's and Eugenius's calls to arms and were ready to embark against their pagan neighbours in the summer of 1147. The motivation for embarking on the Baltic campaigns and the corollary vocabulary employed by Bernard in his letters preaching the Wendish expedition have given rise to much debate. Bernard wrote that the Christians were armed to exterminate or convert the pagan peoples (nationes). He prohibited the Christians from making agreements with the Wends for money or tribute until either the pagan rite or the people (natio) were destroyed. Such a suggestion was of course counter to both canon law and Christian theology. According to Kahl, Bernard believed the Last Days were imminent. Unusual things could therefore happen, perhaps including the forceful baptism of the pagan Wends or their extermination should they fail to convert. Friedrich Lotter reads Bernard's letters differently. He suggests that when the abbot called for the destruction of Wendish natio(nes), he was referring to the pagan peoples' tribal communities. The choice was not between conversion or death; conversion was inevitable. The choice was between conversion while continuing to exist in their existing tribal units and under their own chiefs, or the destruction of their political organisation and subjugation by foreign Christian rulers. ${ }^{84}$

In his contribution to the present volume, Jay T. Lees maintains that the ambiguous terminology employed by Bernard in his letters of exhortation reflects the abbot's desire to attract warriors and churchmen with multifaceted concerns for an ill-defined venture. Tradition holds that people were motivated to embark on the Wendish campaign for several reasons. ${ }^{85}$ Eric Christiansen, for example, suggests that the expedition provided the Danes with an opportunity to seek revenge against Slav pirates and slavers. For the Poles, it was simply a chance to intimidate the 'Prussians'. The Saxons were only interested in the receipt of tribute: 'They did not want to kill the goose that laid the eggs, even for the good of their souls'. ${ }^{86}$ It seems that the Danes, Saxons and Poles were united in their pursuit of their non-

82 Otto of Freising, Gesta Frederici, I.43 (pp. 210-13) and The Deeds of Frederick Barbarossa, pp. 76-78; Bernard of Clairvaux, 'Epistolae', pp. 432-33 (no. 457) and The Letters of St. Bernard of Clairvaux, pp. 466-68 (no. 394).

83 Eugenius III, no. 3, in Pommersches Urkundenbuch, 1: 36-37, reprinted in Kahl, 'Crusade Eschatology', pp. 43-44.

84 Bernard of Clairvaux, 'Epistolae', pp. 432-33 (no. 457) and The Letters of St. Bernard of Clairvaux, pp. 466-68 (no. 394); Hehl, Kirche und Krieg im 12. Jahrhundert, pp. 134-35; Kahl, 'Crusade Eschatology', pp. 35-48; Hans-Dietrich Kahl, 'Wie kam es 1147 zum 'Wendenkreuzzug”?', in Europa Slavica - Europa Orientalis: Festschrift für Herbert Ludat zum 70. Geburtstag, ed. Klaus-Detlev Grothusen and Klaus Zernack (Berlin, 1980), pp. 286-96; Friedrich Lotter, 'The Crusading Idea and the Conquest of the Region East of the Elbe', in Medieval Frontier Societies, ed. Robert Bartlett and Angus MacKay (Oxford, 1989), pp. 267-306 (here pp. 286-92); Jay T. Lees, Anselm of Havelberg: Deeds into Words in the Twelfth Century (Leiden, 1998), p. 76.

85 Johannes Schultze, 'Der Wendenkreuzzug 1147 und die Adelsherrschaften in Prignitz und Rhingebiet', Jahrbuch für Geschichte des deutschen Ostens 2 (1953), 95-125 (here 96-97); Hans-Dietrich Kahl, Slawen und Deutsche in der brandenburgischen Geschichte des zwölften Jahrhunderts: Die letzten Jahre des Landes Stodor (Köln, 1964), pp. 225-27. 
pious aims. As Tyerman states, 'politics got the better of piety'. ${ }^{87}$ Lees concurs with the traditional interpretation. But he argues that many of the various lords who campaigned against the Baltic Slavs were compelled to participate owing to their individual geopolitical concerns. Not all of the major contributors in the expedition were willing participants in some sort of shared endeavour.

In a contribution that assesses Polish involvement in the events of $1147^{-48}$ from a broad chronological perspective, Darius von Güttner-Sporzyński suggests that political expediency and pious concerns were not mutually exclusive. Both concepts underscored a desire to campaign around the southern shore of the Baltic Sea. He argues this was especially true of the Polish Piast dynasty that looked to promote and participate in holy war and the Wendish campaign in pursuit of political and territorial ambitions and obligations. While throwing valuable light on an otherwise rather inaccessible corpus of Polish scholarship, Güttner-Sporzyński maintains that a Polish contingent probably headed by the Piast Junior, Henry of Sandomierz, encountered the army led by Louis VII of France in Anatolia. He also suggests that an expedition against pagan Prussians undertaken in the last months of 1147 and led by the Piast suzerain of Poland, Bolesław IV the Curly, should be seen as a corollary of the Wendish campaign.

Güttner-Sporzyński agrees with a strand of Polish historiography in maintaining that a papal legate, one Cardinal Hubaldus, preached in Poland. He was probably the same legate who may have preached for the eastern expedition in Denmark. The Danish archbishop, Eskil of Lund, a friend of Bernard of Clairvaux, is known to have encouraged the warring Danish kings, Knud V and Svend III, to participate in the Baltic campaign. Both kings subsequently took the cross. The rapid response to Bernard's and Eugenius's extension of their initial enterprise suggests that warriors and churchmen of northern Europe had already begun to put their affairs in order, and that a call to arms was widespread in Poland, Denmark and northern Germany before Eugenius issued his third bull. We have noted that a number of German nobles vowed to campaign against their pagan enemy at the Council of Frankfurt am Main in March 1147. Sources such as the Würzburg annalist refer to many Christian knights assuming the cross, but very little evidence has come to light of individuals undergoing the actual rite for taking the cross before embarking on the Wendish campaign. ${ }^{88}$ Similarly, there is no evidence of the warriors involved on the Prussian campaign performing the rite before marching against their enemy. Nonetheless, Güttner-Sporzyński conjectures that the Piasts planned the latter expedition in response to prior Bernardine inspired preaching and the issuing of Divina dispensatione (II).

John H. Lind proposes that the call to arms of Bernard of Clairvaux and Pope Eugenius III influenced Christian-pagan conflict in a further theatre of war. In another contribution that views the events of the mid-twelfth century from a wide chronological

${ }^{86}$ Eric Christiansen, The Northern Crusades: The Baltic and the Catholic Frontier, 1100-1525, 2nd edn (London, 1997), pp. 53-56.

87 Tyerman, God's War, pp. 305-8.

88 ‘Annales Magdeburgenses', p. 188; Saxo Grammaticus, Gesta Danorum, ed. Karsten Friis-Jensen, trans. Peter Zeeberg, 2 vols (København, 2005), XIV.3. 5 (2: 162-63); Otto of Freising, Gesta Frederici, I.43 (pp. 210-13) and The Deeds of Frederick Barbarossa, pp. 76-78; Bernard of Clairvaux, 'Epistolae', pp. 432-33 (no. 457) and The Letters of St. Bernard of Clairvaux, pp. 466-68 (no. 394); Vincent of Prague, 'Annales', ed. Wilhelm Wattenbach, in MGH SS, 17: 654-84 (here 662-63); Kurt Villads Jensen, 'Denmark and the Second Crusade: The Formation of a Crusader State?', in Second Crusade, ed. Phillips and Hoch, pp. 164-79 (here pp. 165 and 177, n. 3); Janus Møller Jensen, 'Denmark and the Holy War: A Redefinition of a Traditional Pattern of Conflict 1147-1169', in Scandinavia and Europe, 800-1350: Contact, Conflict, and Coexistence, ed. Jonathan Adams and Katherine Holman (Turnhout, 2004), pp. 219-36 (here pp. 223-24). 
perspective, Lind suggests that a Swedish campaign known as the 'First Swedish Crusade', conducted against pagan Finns and traditionally dated to the late $1150 \mathrm{~s}$, may in fact have taken place around the same time as the Wendish campaign. Swedish bishops remained suffragans of the Danish archbishopric at this point, and Cardinal Hubaldus seems to have preached in Denmark. The paucity of extant medieval records in Scandinavia, however, virtually guarantees that there is no evidence of individuals assuming the cross before embarking on the Swedish enterprise. As Lind points out, there is no extant papal bull proclaiming the expedition against the Finns either. Nonetheless, even if the conventional yet problematic dating of the expedition is accepted, Lind maintains that Eugenius's and Bernard's call to arms may have been interpreted in Sweden as a proclamation of a 'perpetual' campaign against all the pagans in the region. Either way, he conjectures, the 'First Swedish Crusade' was conceived within the same Bernardine ideological framework as the Wendish campaign.

The expeditions against the Wends had two parts. A combined Saxon army was headed by Duke Henry the Lion of Saxony and supported by the Danish fleets of the rival kings Knud V and Svend III. This force unsuccessfully besieged the remote and newly fortified pagan Abrodite outpost at Dobin on Lake Schwerin in July 1147. Margrave Albert the Bear and the papal legate, Anselm of Havelberg, led a second force. The army may have included a Polish contingent headed by the Piast prince, Mieszko III the Old. The combined forces set out from Magdeburg in late July and advanced towards the territory of the pagan Liutizians. After the capture of Havelberg, the army pushed on to unsuccessfully besiege Liutizian Demmin on the River Peene. A contingent led by Albert the Bear continued east to the gates of the western Pomeranian trading station of Szczecin. Here Albert discovered that the town was already in Christian hands, which effectively put an end to the Wendish campaign.

Whilst evidence of individuals taking the cross and publicly vowing to campaign against the pagan Slavs is not extensive, the Wendish expeditions were legitimised by Pope Eugenius III and preached by the Church. The most widely held 'pluralist' definition of a crusade accepts that crusades were a form of service performed for Christ, preached by the Church, and proclaimed and sanctioned by the heirs of St Peter. As such, crusades could be directed against the enemies of the papacy wherever they might be found. Individuals were called to fight on behalf of Christendom, and, according to the pluralist definition, at least some of the participants embarking on an expedition must have publicly taken a vow to campaign in a certain theatre. In return for their vow, the combatants assumed the Saviour's cross in imitatio Christi and received valuable privileges of a temporal and spiritual nature predicated on the papacy's magisterium and the Church's role as spiritual mediator. ${ }^{89}$ Given this widely held definition, it would appear that the Wendish campaigns along with the Syrian expedition should be seen as crusades, and there would seem to be little reason to argue that the Wendish campaigns did not form part of the Second Crusade.

89 Giles Constable was the first to identify four different definitions of a crusade. See his 'The Historiography of the Crusades', in The Crusades from the Perspective of Byzantium and the Muslim World, ed. Angeliki E. Laiou and Roy Parviz Mattahedeh (Washington, D.C., 2001), pp. 1-22 (here pp. 12-15). A revised and updated version can be found in Constable, Crusaders and Crusading in the Twelfth Century (Aldershot, 2008), pp. 3-43. For an excellent detailed analysis of the approaches to defining a crusade see Norman Housley, Contesting the Crusades (Malden, Mass., 2006), pp. 1-23. Tyerman argues that to define campaigns undertaken before the thirteenth century as crusades is anachronistic. See Christopher J. Tyerman, The Invention of the Crusades (Basingstoke, 1998). More recently, he has described crusades in line with the pluralist approach in his Fighting for Christendom: Holy War and the Crusades (Oxford, 2004), pp. 30-32. 
The Prussian and Finnish campaigns, and indeed the expedition of Jarl Rognval and Erling Skakke in 1151, do not adhere to the so-called pluralist definition. Nonetheless, Güttner-Sporzyński, Lind and Jensen maintain that these expeditions were indeed crusades. Their views highlight the problem in defining a crusade. Strict pluralism will not allow that the Prussian campaign was a crusade until, for example, evidence comes to light of individuals taking the cross before embarking on the expedition. Neither will the pluralist definition allow that the voyage of Jarl Rognval and Erling Skakke was a crusade until further evidence is found of, for instance, preaching taking place in Norway and the Scandinavian settlements of the North Atlantic in support of the expedition. Yet analogous evidence suggests that these campaigns did take place in the context of the Wendish and Syrian crusades. Similarly, there is no evidence that the campaign traditionally known as the "First Swedish Crusade' was proclaimed or sanctioned by the papacy, preached by the Church, or that those who campaigned against the Finns had taken the cross. Yet the campaign has been considered a crusade for many years, as have the Swedish campaigns undertaken in near perpetuity like the thirty- to forty-year 'crusade' against the pagan Karelians referred to in Lind's contribution. These Swedish campaigns were not crusades according to the pluralist formula. $^{90}$

A similar situation arises when the campaigns in Iberia are considered. A heterogeneous fleet of north European warriors sailed out from the Dart estuary in May 1147 with the intention of sailing to the Levant and fighting in the holy war. The fleet stopped en route and assisted the Portuguese ruler, Afonso Henriques, in his siege of Muslim-held Lisbon, which fell to the allied forces on 24 October. Harold Livermore argues that a letter of questionable authenticity purportedly written by Bernard of Clairvaux to Afonso is in fact genuine. He argues that the letter demonstrates that Afonso had requested the abbot's assistance in recruiting forces to help him in Portugal. ${ }^{91}$ Drawing on Livermore's argument, Phillips agreed that the northern Europeans' participation in the siege of Lisbon was premeditated. He also pointed out that Bernard of Clairvaux spent around three months preaching the holy enterprise in the Low Countries and had met Christian of Ghistelles, the leader of the besiegers' Flemish contingent. ${ }^{92}$ Forey, however, forcefully restates that Bernard's supposed letter is indeed a forgery. He also argues that other evidence relating to Bernard's alleged support of an attack on Lisbon is unconvincing. ${ }^{93}$ Phillips has since nuanced his interpretation of this central point of contention. He suggests that upon hearing of the crusading plans, Afonso probably made contact with the Church authorities and with northern Europeans with whom he was familiar. Afonso's aim was to ensure that the fleet sailed to Lisbon with the hope of advancing Christianity and securing the financial rewards that a successful siege might bring. ${ }^{94}$ The two most important sources for the siege of Lisbon, De expugnatione Lyxbonensi and the so-called 'Lisbon Letter', both demonstrate that the Portuguese ruler knew of the fleet's existence before it reached Lisbon. However, this does not prove that the attack on Lisbon was premeditated. And as Forey points out, the former source indicates that the negotiations which resulted in the allied attack on Lisbon did not

90 Also see Thomas Lindkvist, 'Crusades and Crusading Ideology in the Political History of Sweden, 1140-1500', in Crusade and Conversion on the Baltic Frontier, 1150-1500, ed. Alan V. Murray (Aldershot, 2001), pp. 119-30.

${ }^{91}$ Harold Livermore, 'The Conquest of Lisbon and Its Author', Portuguese Studies 6 (1990), 1-16.

92 Jonathan Phillips, 'St Bernard of Clairvaux, the Low Countries and the Lisbon Letter of the Second Crusade', Journal of Ecclesiastical History 48 (1997), 485-97.

93 Alan J. Forey, 'The Siege of Lisbon and the Second Crusade', Portuguese Studies 20 (2004), 1-13.

94 Phillips, Second Crusade, pp. 139-42. 
commence until the fleet had made landfall in Portugal. He concludes that the fleet was essentially persuaded to assist Afonso only after reaching Lisbon (presumably to collect provisions). The crusaders had not, therefore, initially intended to assist Afonso Henriques in his on-going siege. ${ }^{95}$ In her contribution to the present volume, Susan B. Edgington attempts to steer a path between the theories of Forey and Phillips. In agreement with Phillips, she maintains that Afonso knew of the existence of the fleet before any of its ships made landfall in Iberia. Edgington also hypothesises that Afonso knew when the main fleet was likely to make landfall near Lisbon and made preparations to receive it. Like Forey, however, she concludes that the crusaders only agreed to assist Afonso after they had disembarked in Iberia, and it would therefore be very difficult to view the crusaders' actions at Lisbon as forming part of a preconceived Cistercian plan to attack the enemies of Christendom on three broad fronts. Indeed, Forey maintains that the events at Lisbon should only be viewed as an episode in the ongoing Christian-Muslim conflict in Iberia. ${ }^{96}$ Stephen Lay adds that Afonso simply took the opportunity afforded by the arrival of the fleet to extend and consolidate his own demense. ${ }^{97}$ Tyerman submits that Afonso saw the arrival of the fleet as an opportunity to exploit the political collapse of the previously dominant Almoravids in al-Andalus and the temporary disunity of the Taifas, the independent petty Muslim kingdoms created in the wake of the Almoravid collapse. The capitulation of Lisbon would reinforce Afonso's credentials as a Christian king worthy of papal recognition. It would also further assert his independence from his nominal overlord, the emperor Alfonso VII of León-Castile. ${ }^{98}$ It seems that Afonso's decision to besiege Lisbon was not encouraged by Eugenius's and Bernard's propagation of holy war.

Luis García-Guijarro views the contemporaneous Christian attacks on Muslim Almería and Tortosa in a similar vein. The letter Divina dispensatione (II), issued in April 1147, referred to the Christian-Muslim conflict in the Iberian Peninsula; a year later, the pope appeared to make reference to privileges offered to those that had fought at Almería in 1147 or perhaps Jaén in 1148; and Eugenius III also offered the remission of sins to those that fought alongside Count Ramón Berenguer IV of Barcelona. Ramón Berenguer captured Tortosa in 1148 and the inland city of Lérida and the outlying castles of Fraga and Mequinenza in the last months of $1149 .{ }^{99}$ These Muslim cities and strong points had long been the subject of native Christian attention and aggression; indeed, the origins of the campaigns that led to their conquest were conceived in Iberia. Whilst there is no unequivocal evidence of individuals taking the cross before embarking on any of these expeditions, warriors and churchmen alike employed the rhetoric of holy war in propagation of the operations and the campaigns were clearly endorsed by the Church authorities. ${ }^{100}$ García-Guijarro recognises that Christian aggression against Muslim peoples in the Iberian Peninsula had been imbued with

95 De expugnatione Lyxbonensi, p. 68; Edgington, 'The Lisbon Letter and the Second Crusade', p. 337; Forey, 'The Second Crusade: Scope and Objectives', pp. 168-69. Similarly, James O'Callaghan suggests that the arrival of the fleet was merely coincidental. See his A History of Medieval Spain (Ithaca, 1975), pp. 41-44, 230 .

${ }^{96}$ Forey, 'The Second Crusade: Scope and Objectives', pp. 168-69.

97 Stephen Lay, 'The Reconquest as Crusade in the Anonymous De expugnatione Lyxbonensi', Al-Masaq 14 (2002), 123-30.

98 Tyerman, God's War, pp. 308-17.

99 Eugenius III, no. 3, in Pommersches Urkundenbuch, 1: 36-37, reprinted in Kahl, 'Crusade Eschatology', pp. 43-44; Eugenius III, 'Epistolae et privilegia', in PL, 180: 1346 (no. 295); Colección de documentos inéditos del Archivo general de la Corona de Aragón, ed. Próspero de Bofarull y Mascaró and others, 42 vols (Barcelona, 1847-1910), 4: 314-15 (no. 128). This latter bull is traditionally dated to 1147 or 1148 although see García-Guijarro's discussion on this point in the present volume. 
notions of holy war since the ninth century. In taking a broad chronological perspective, however, he argues that the Christian-Muslim conflicts in Iberia, typified by the conquest of Tortosa on the Ebro in December 1148 by the Genoese, the warriors who had fought at Lisbon and Ramón Berenguer IV of Barcelona, as well as the latter's successful attack on Lérida, were not what he calls 'proper crusades'. He supposes that Christian protagonists pursued a distinct native ideology of holy war, that of the Reconquista, in furtherance of their expansionist policies. This was at the very time when political relations within and between the Christian kingdoms and counties and the disintegration of Almoravid power in al-Andalus made expansion possible. According to García-Guijarro, the 'practice of crusading' was merely one weapon in a ruler's arsenal, and certainly not the principal factor influencing Christian expansion in Iberia.

Strict advocates of the 'pluralist' approach to crusade history would like to see evidence of all of the prescribed devotional and juridical formulae in Iberia (and indeed the Baltic region and the Scandinavian settlements of the North Atlantic) before accepting that all of the above identified campaigns were crusades. It would follow that not all of these campaigns can be considered as forming part of the Second Crusade in the absence of the constituent parts of the formulae. Nevertheless, Constable, Phillips, Simon Barton, Nicholas Jaspert and John Williams all argue that the campaigns against Almería, Lisbon, Tortosa and Jaen were crusades even given an absence of prescribed formula in the textual record. Indeed, historians tend to agree that the campaigns should be considered as forming part of the Second Crusade, while recognising that native and foreign religious zeal, long-term geopolitical strategic goals and the hope of commercial and material gain dovetailed in the Iberian Peninsula. ${ }^{101}$

The warrior and commercial elite undoubtedly had various temporal reasons for engaging in warfare in Iberia and indeed in the Baltic region. Warfare between Christians and Muslims and Christians and pagans predated the issuing of Divina dispensatione (II) and it would continue long after 1149 . When viewed from a broader chronological perspective, it becomes easy to see that the Christian offensives undertaken between 1147 and 1149 on the north-eastern and western peripheries of Christendom fit into an established pattern of worldly aggression and expansion. Normal temporal aspirations were not suspended during these years. It is possible, even likely, that Christian aggression in Iberia and the Baltic area would have occurred without papal and clerical support.

The same broad chronological perspective also reveals a long established concern with spiritually rewarding warfare, and religious concerns intertwined with temporal motives in the minds of contemporaries. God rewarded spiritually meritorious acts with earthly gains. Even though the conflicts took place on the periphery of Christendom, the wars were of a type that

100 Constable, 'The Second Crusade as Seen by Contemporaries', pp. 228-35, 257-60; Phillips, Second Crusade, pp. 136-67, 244-68; Nicholas Jaspert, 'Capta est Dertosa, clavis Christianorum: Tortosa and the Crusades', in Second Crusade, ed. Phillips and Hoch, pp. 90-110; Simon Barton, 'A Forgotten Crusade: Alfonso VII of León-Castile's Campaign for Jaen (1148)', Historical Research 73 (2000), 312-20; Rudolf Hiestand, 'Reconquista, Kreuzzug und Heiliges Grab: Die Eroberung von Tortosa 1148 im Lichtes eines neuen Zeugnisses', Gesammelte Aufsätze zur Kulturgeschichte Spaniens 31 (1984), 136-57; John Bryan Williams, 'The Making of a Crusade: The Genoese Anti-Muslim Attacks in Spain, 1146-1168', Journal of Medieval History 23 (1997), 29-53.

101 Constable, 'The Second Crusade as Seen by Contemporaries', pp. 228-35, 257-60; Phillips, Second Crusade, pp. 136-67, 244-68; Jaspert, 'Capta est Dertosa', pp. 90-110; Barton, 'A Forgotten Crusade', pp. 312-20; Hiestand, 'Reconquista, Kreuzzug und Heiliges Grab', pp. 136-57; Williams, 'The Making of a Crusade', pp. 29-53. 
was deep rooted in Christendom's central structures. ${ }^{102}$ Supported by the papacy, incorporated into the Church's penitential system and powerfully associated with the ideals of Christian knighthood, the wars were fought within the ideological context of holy war. It would be problematic to consider the rhetoric of individuals who professed to engage in holy war as merely propaganda, or perhaps no more than window dressing arranged to conceal processes of conquest, subjugation and extraction. To do so would be to deny a mass of evidence revealing that such activity was considered spiritually beneficial. This approach would also make light of the spiritual anxiety prevalent in the medieval mind where the pains of 'purgatory', the horrors of hell and the glory of heaven were no less real than the bloody sword in a warrior's hand.

Attempting to secure and expand the peripheries of Christendom and engaging in penitential warfare was often the same thing. The tumultuous events in the Near East in 1144 that gave rise to subsequent papal bulls and Bernardine inspired preaching coincided with, for instance, advantageous geopolitical circumstances in the Iberian Peninsula that expedited Christian territorial expansion. And the ubiquitous medieval concern for the soul was no less important to contemporaries than the desire for material gain and the acquisition of land. It is impossible to prove, for example, that those Christians who campaigned annually against the pagan Wends and did so again in 1147 did not share similar spiritual anxieties with those warriors who vowed to march to Jerusalem. There is a danger in clinically construing motivation from behaviour in such instances. The evidence does not allow a neat separation of religious from worldly matters. As noble warriors, those that fought in Iberia and the Baltic region had temporal ambitions and obligations. The warriors in each region had also been familiar with the notion of spiritually rewarding warfare since at least the second half of the eleventh century and these same warriors were instrumental in seeking papal and clerical support for their military actions. In other words, they endeavoured to secure spiritual privileges in pursuit of long held political and commercial ambitions. The initiatives undertaken were - to varying degrees - championed by Eugenius III, Bernard of Clairvaux and others who preached in support of the various campaigns. Consequently, in Iberia the native rulers were able to engage their enemies with allied Christian support. Christian forces campaigning around the southern shore of the Baltic Sea were able to ally together to form substantial armies while securing indulgences for their subsequent actions.

It is important to recognise that circumstances conspired between 1145 and 1149 to unite with a fundamental principle which the Church authorities actively propagated: the relationship between this world and the next was governed by cause and effect. This was Bernard's 'time of jubilee' and surely in the mind of churchmen and warriors alike, these years provided the opportunity to engage in reciprocal behaviour. The circumstances dovetailed with the penitential notion of quid pro quo: the Church taught that, at least in theory, penitential acts could suffice to wash away sin and warriors took up arms replete with this knowledge. This concept was both a central plank of the laity's religious thinking and undeniably at the very heart of the crusading message.

As the foregoing discussion has demonstrated, however, there is little consensus amongst historians of what is meant by the terms 'crusading', 'crusade' and 'crusader'. Certainly, the so-called pluralist 'school of thought' finds little favour in this volume where the terms are often employed without reference to (and in the absence of) any prescribed devotional and juridical formulae. This may suggest that the pluralist approach, with its focus on procedure and ritual, is problematic owing to one very simple reason: the lamentable dearth of extant documents in some regions.

${ }^{102}$ Ernst-Dieter Hehl, 'Was ist eigentlich ein Kreuzzug?', Historische Zeitschrift 259 (1994), 297-336. 
One thing though seems to connect all the campaigns which contributors to the volume and the other historians noted above see as an integral constituent of the Second Crusade: Eugenius III's promotion of holy war. Unsurprisingly, chroniclers and annalists were unaware of the extent of the pontiff's support for the campaigns, but these were still righteous acts of violence that contemporaries viewed as directed against different targets and for which they could justly fight for both spiritual and temporal gain. Even though Eugenius endorsed existing initiatives, it does seem reasonable to suggest that a common link is evident connecting the Syrian, Iberian and Baltic campaigns within the same contextual enterprise if his espousal of holy war had some bearing on the Christian aggression in those three regions. No preconceived plan was needed for this to happen, and yet the pontiff's support of the various expeditions seems to bind them (or the crusade) together. Warriors marched against the pagan Wends residing around the southern shore of the Baltic Sea and against the Muslims living in the Levant and Iberia secure in the knowledge that they would receive the indulgence for doing so. Güttner-Sporzyński, Lind and Jensen would argue that those who took part in the campaigns against the Prussian and Finnish pagans and in the expedition to the Holy Land in 1151 likewise hoped to acquire God's merit in return for their actions. If so, and if Eugenius and the curia did influence these campaigns, should they now be considered as forming part of the enterprise known as the Second Crusade? 

